\title{
The socioeconomic variables influence in the alpha-tocopherol concentration of the maternal serum
}

\author{
Karla Danielly S. Ribeiro 1 \\ Luana Weigert 2 \\ Talita Andrade 3 \\ Amanda Lima 4 \\ Jeane Medeiros 5 \\ Mayara Lima 6 \\ Danielle Bezerra 7 \\ Mônica Osório 8 \\ Roberto Domenstein 9
}

\begin{abstract}
1-4,6 Departamento de Nutrição. Universidade Federal do Rio Grande do Norte. Senador Salgado Filho, 3000. Lagoa Nova. Natal, RN, Brasil. CEP: 59.078-970. E-mail: karladaniellysr@yahoo.com.br

5,9 Departamento de Bioquímica. Universidade Federal do Rio Grande do Norte. Natal, RN, Brasil.

7 Faculdade de Ciências Médicas do Trairi. Universidade Federal do Rio Grande do Norte. Natal, RN, Brasil.

8 Universidade Federal de Pernambuco. Recife, PE, Brasil.
\end{abstract}

\begin{abstract}
Objectives: To evaluate the influence of the socioeconomic factors on the alpha-tocopherol concentration in maternal serum.

Methods: a retrospective, observational, cross-sectional study with the participation of 103 adult parturient volunteers attended at Hospital Universitário Ana Bezerra (Ana Bezerra University Hospital) in Santa Cruz - Rio Grande do Norte. $5.0 \mathrm{~mL}$ of blood was collected from each participant in fasting before the delivery to extract alpha-tocopherol of the serum. Socioeconomic and demographic information were obtained by a previously structured questionnaire. Alpha-tocopherol serum was determined by a High-Performance Chromatography Liquid (Cromatografia Líquida de Alta Eficiência (CLAE).

Results: The average concentration of alpha-tocopherol in the serum was 1281.4 (594.8) $\mu \mathrm{g} / \mathrm{dL}$, and $6 \%$ of the women presented vitamin E deficiency (DVE). Most pregnant women aged between 18 and 24 years (59\%), marital status was married or consensual marriage (77\%), elementary schooling complete (34\%), low family income (74\%) and living in the urban area (73\%). No significant differences were found in the alpha-tocopherol concentration according to socioeconomic characteristics and none of the studied factors were associated to the presence of DVE $(p>0.05)$.

Conclusions: The maternal social characteristics were not determinants for the alphatocopherol serum and DVE. Further investigations should be carried out during lactation to assess which factors may be involved in the presence of this deficiency.
\end{abstract}

Key words Vitamin E, Vitamin E deficiency, Pregnancy, Per capita income 


\section{Introduction}

Pregnancy is characterized by physiological and metabolic alterations in response to fetal growth, which demands the necessity of specific nutrition for that period. Thus, the pregnant women's nutritional status is a particular concern in regions where the nutritional deficiency is a public health problem. ${ }^{1}$

Vitamin $\mathrm{E}$ is one of the nutrients that deserve the attention during pregnancy. The alpha-tocopherol serum concentration, in its most active form, increases during this period mainly at the end of the last quarter of the gestation, probably due to the maternal lipophilic activity increase to ensure the transfer of essential polyunsaturated fatty acids for the fetus to grow. 2,3

The interest of this vitamin mainly should be of its antioxidant capacity, which protects the lipoproteins and lipids on the cell membranes against free radical damage. 4

The maternal nutritional status in vitamin $\mathrm{E}$ has a direct relationship with the alpha-tocopherol serum levels of the fetus and newborn, highlighting that at the border or low value levels of alpha-tocopherol in the maternal plasma may indicate vitamin E deficiency for the mother-child binomial, 5 and for this reason why it is essential to monitor these and its determining factors during the gestation and postpartum. When present, the deficiency in neonates is associated to hemolytic anemia, bilirubin, thrombocytosis, intracranial hemorrhage and retrolental fibroplasia. 6,7

There are few studies that investigate the associated factors with maternal vitamin E deficiency (DVE). Gurgel et al. 8 found a high prevalence of the deficiency in women attended for the delivery in public maternities when compared to those attended at a private health network. Dimenstein et al. ${ }^{9}$ found no differences in the alpha-tocopherol serum level according to maternal age; and another study also found no differences in this micronutrient in parturient according to age, parity and gestational weight gain. 10

As it is known in the environment, permeated by material conditions of life and by the access to health services and schooling, it determines characteristic patterns of health and disease. Variables such as family income, schooling level and among others can be conditional, at the last instance, family insertion in the process of production, reflecting for example, in the acquisition of food and consequently in the nutritional situation. ${ }^{11}$

The importance of an adequate maternal nutritional status of vitamin $\mathrm{E}$ for the fetal health and the neonate and the limitation of data on the subject, it is necessary to investigate whether socioeconomic variables are related to the concentration of alphatocopherol serum level and DVE in pregnant women attended for delivery in a public maternity in the Northeast of Brazil.

\section{Methods}

This is a retrospective observational cross-sectional study, developed with adult pregnant women with gestational age $\geq 37$ weeks, attended for delivery in the period of 2013 to 2014 at the Hospital Universitário Ana Bezerra (HUAB) - Universidade Federal do Rio Grande do Norte (UFRN), Santa Cruz - RN.

The city of Santa Cruz has about 35,797 inhabitants (as of 2010) and is located in the Mesoregion of the countryside region, and the HUAB is the only public maternity hospital with reference in obstetrical and pediatric care in Trairi region. This study was approved by the Ethics Committee in Research at UFRN (document number: CAAE 07416912.8. 0000.5537).

Women who were not included in this study were the ones diagnosed with diabetes, hypertension, neoplasia, gastrointestinal tract diseases, liver disease, infectious diseases, heart disease; malformations, and those who take vitamin supplements containing vitamin $\mathrm{E}$ during pregnancy. The socioeconomic and demographic information were obtained within the first 24 hours after the delivery, through medical records and semi-structured interview.

From Monday to Thursday at the admission before the delivery, all women who were apt to participate were clarified about the objectives and methodology of the research. After the authorization of signing the informed consent form, a $5 \mathrm{~mL}$ of blood was collected by vein puncture. The women were fasting for 6 to 12 hours.

The blood was centrifuged for 5 minutes (500 $\mathrm{xg}$ ) to remove the serum and store at $-20^{\circ} \mathrm{C}$ until they were transported under refrigeration to the Biochemistry Laboratory of Food and Nutrition Department (Laboratório de Bioquímica dos Alimentos e da Nutrição do Departamento de Bioquímica) at UFRN, where they were extracted and analyzed. The time elapsed between the collection and the analysis of the serum was about seven days.

The extractive technique for the alpha-tocopherol in the serum was adapted by Ortega et al.,12 where for each aliquot of $1 \mathrm{~mL}$ of serum $1 \mathrm{~mL}$ of 
ethanol at $95 \%$ were used (Merck ${ }^{\circledR}$ ) for protein precipitation, and $2 \mathrm{~mL}$ of hexane (Merck ${ }^{\circledR}$ ) for the lipids extraction. Afterwards, the samples were homogenized for 1 minute and centrifuged for 10 minutes, after which the hexane extract was transferred to another tube. The addition of $2 \mathrm{~mL}$ of hexane was repeated two more times for a total of 6 $\mathrm{mL}$ of extract, which was withdrawn an aliquot of 3 $\mathrm{mL}$ for evaporation in a water bath at $37^{\circ} \mathrm{C}$.

At the time of the analysis, the dry extract was dissolved in $250 \mu \mathrm{L}$ of absolute ethanol (Merck ${ }^{\circledR}$ ) and $20 \mu \mathrm{L}$ were applied in the Shimadzu LC-21 AT Chromatograph, coupled to a Detector SPD-20A Shimadzu UV-VIS, Phenomenex Luna column $5 \mu \mathrm{m}$ C18 $250 \times 4.6 \mathrm{~mm}$ and a computer with LC Solution software for data processing.

The mobile phase used was Methanol in isocratic system with the flow of $1.0 \mathrm{~mL} /$ minute, in wave length of $292 \mathrm{~nm}$. The identification and quantification of the alpha-tocopherol in samples were established by comparison at peak areas obtained in the chromatogram with an area of its respective pattern for alpha-tocopherol (SIGMA ${ }^{\circledR}$ ). The standard concentration was confirmed by the specific coefficient extinction for alpha-tocopherol (and $1 \%, 1 \mathrm{~cm}$ $=75.8$ to $292 \mathrm{~nm})$ in absolute ethanol (Merck $\left.{ }^{\circledR}\right) .13$

Alpha-tocopherol concentrations in maternal serum were less than $517 \mu \mathrm{g} / \mathrm{dL}$ indicating vitamin $\mathrm{E}$ deficiencies. It was considered for analysis the variables for family income per capita, schooling and area of residency (rural or urban). The information on the monthly family income per capita was used as a reference to the minimum wage in 2013 , the value was of R\$ 678.00 (six hundred and seventy-eight reais - Brazilian currency) divided by the number of the household members. The schooling level was classified as literate, elementary schooling completed, high school incomplete, high school completed and superior level.

The values of alpha-tocopherol were described in $\mu \mathrm{g} / \mathrm{dL}$ and expressed in mean (standard deviation). The normality of the samples was evaluated by using the Kolmogorov-Smirnov test using normal distribution. The differences in the concentration of alphatocopherol serum according to the classification of each variable were analyzed by the Student $t$ test for independent samples (residential area) and by the Variance Analysis with Tukey post test (income, schooling).

To assess the influence of socioeconomic variables on vitamin E deficiency a calculation of odds ratios was carried out (odds ratios - OR; confidence interval), assuming as the variable response of alphatocopherol values $<517 \mu \mathrm{g} / \mathrm{dL}$ and $\geq 517 \mu \mathrm{g} / \mathrm{dL}$. The statistical software used was the IBM SPSS version 21.0 for Windows (SPSS Inc., Chicago, IL, USA). All the values were considered significant when $p<0.05$.

\section{Results}

Of the 103 pregnant women enrolled in the study, most of them were between 18 to 24 years old $(n=61$, $59 \%)$, were married/consensual marriage $(n=79$, $77 \%$ ), elementary schooling level completed (47\%), residing in the urban area of the city $(73 \%)$ and a family income per capita up to a minimum wage $(74 \%, \mathrm{n}=76)$ (Table 1).

Table 1

Concentration of alpha-tocopherol in the serum of women attended for childbirth according to socioeconomic characteristics. Santa CruzRN, 2013-2014.

\begin{tabular}{|c|c|c|c|c|}
\hline Characteristics & $\mathbf{N}$ & $\%$ & Mean (standard deviation) $\mu \mathrm{g} / \mathrm{dL}$ & $\boldsymbol{P} *$ \\
\hline \multicolumn{5}{|l|}{ Schooling } \\
\hline Literate & 13 & 13 & $1,479.61(524.24)$ & 0.103 \\
\hline Elementary schooling completed & 35 & 34 & $1,312.02(714.95)$ & \\
\hline High School incomplete & 20 & 19 & $1,231.47(592.30)$ & \\
\hline High School completed & 30 & 29 & $1,257.38(498.25)$ & \\
\hline Superior Level Education & 5 & 5 & $896.35(215.63)$ & \\
\hline \multicolumn{5}{|l|}{ Residence } \\
\hline Rural area & 28 & 27 & $1,333.51(413.90)$ & $0.590 * *$ \\
\hline Urban area & 75 & 73 & $1,262.00(650.89)$ & \\
\hline \multirow{2}{*}{\multicolumn{5}{|c|}{$\begin{array}{l}\text { Family income per capita (minimum } \\
\text { wages) }\end{array}$}} \\
\hline & & & & \\
\hline Up to 1 & 76 & 74 & $1,327.90(643.09)$ & 0.484 \\
\hline 1 to 2 & 21 & 20 & $1,176.34(451.89)$ & \\
\hline 3 to 5 & 6 & 6 & $1,060.81(241.18)$ & \\
\hline
\end{tabular}

* $p$, ANOVA with Tukey post test; ** t test for independent samples. 
Association between the socioeconomic characteristics and vitamin E deficiency of pregnant women attended for childbirth, Santa CruzRN, 2013-2014.

\begin{tabular}{|c|c|c|c|c|c|c|}
\hline \multirow[t]{2}{*}{ Characteristics } & \multicolumn{2}{|c|}{$\begin{array}{c}\text { Vitamin E } \\
\text { deficiency (alpha- } \\
\text { tocopherol <517 } \\
\mu \mathrm{g} / \mathrm{dL} \text { ) }\end{array}$} & \multicolumn{2}{|c|}{$\begin{array}{l}\text { Normal alpha- } \\
\text { tocopherol } \\
\text { serum levels } \\
\text { ( } \geq 517 \mu g / d L)\end{array}$} & \multirow[t]{2}{*}{$O R^{*}(\mathrm{Cl} 95 \%)$} & \multirow[t]{2}{*}{$p^{*}$} \\
\hline & $\mathrm{n}$ & $\%$ & $\mathrm{n}$ & $\%$ & & \\
\hline \multicolumn{7}{|l|}{ Schooling } \\
\hline Up to elementary schooling & 4 & 8.0 & 44 & 92.0 & $2,409(0.421-13,778)$ & 0.414 \\
\hline From high school & 2 & 4.0 & 53 & 96.0 & & \\
\hline \multicolumn{7}{|l|}{ Residence } \\
\hline Rural area & 0 & - & 28 & 100.0 & $1,087(1,017-1,162)$ & 0.186 \\
\hline Urban area & 6 & 8.0 & 69 & 92.0 & & \\
\hline \multirow{2}{*}{\multicolumn{7}{|c|}{$\begin{array}{l}\text { Family income per capita (minimum } \\
\text { wage) }\end{array}$}} \\
\hline & & & & & & \\
\hline$<1$ & 6 & 8.0 & 70 & 92.0 & $0.921(0.862-0.984)$ & 0.192 \\
\hline$\geq 1$ & 0 & - & 27 & 100.0 & & \\
\hline
\end{tabular}

* OR = odds ratio.

The average concentration of alpha-tocopherol in serum of the 103 pregnant women was $1,281.44$ (594.75) $\mu \mathrm{g} / \mathrm{dL}$, and $6 \%(\mathrm{n}=6)$ of the women had lower values than $517 \mu \mathrm{g} / \mathrm{dL}$, classified as vitamin $\mathrm{E}$ deficient. The pregnant women with and without DVE presented alpha-tocopherol serum levels of 379.91 (28.45) and 1,337.20 (567.32), respectively $(p<0.001, \mathrm{t}$ test $)$.

There was no significant difference in the concentration of alpha-tocopherol serum levels among women classified according to schooling, family income and residential area $(p>0.05)$ (Table 1).

None of the studied characteristics was associated to vitamin E deficiency, an odds ratio of 0.92 was found and $95 \%$ confidence interval of 0.86 0.98 for family income per capita $(p>0.05)$ (Table 2).

\section{Discussion}

A suitable antioxidant condition during pregnancy exerts a protective effect on the mother-child binomial, increasing the intrauterine growth and weight at birth, and reducing the oxidative damage caused to the DNA, which may be associated to the complications of pregnancy such as preterm childbirth and preeclampsia. 15,16

Of the total number of pregnant women analyzed $(\mathrm{n}=103)$, there was an average concentration of alpha-tocopherol of 1,281.44 (594.75) $\mu \mathrm{g} / \mathrm{dL}$, inferior to the pregnant women from the same State $(1,940 \mu \mathrm{g} / \mathrm{dL})^{17}$ and similar to the American pregnant women $(1,348 \mu \mathrm{g} / \mathrm{dL}) .18$ These values represent an important indicative for the health of the binomial, since there is evidence that alpha-tocopherol maternal serum is directly related to the neonate. 19,20 An insufficient supply of vitamin $\mathrm{E}$ for the fetus can cause DVE and result in compromising the immune system and lungs, as well as becoming likely to develop after birth hemolytic anemia. ${ }^{6}$

Although most of the participants of this study are in social vulnerability conditions (Table 1), and probably more exposed to micronutrient deficiency, only $6 \%(n=6)$ presented DVE. This same prevalence was found in pregnant women attended at the public maternity hospitals in the city of Natal-RN. 8 Wondmikun ${ }^{1}$ found $42 \%$ of low alpha-tocopherol levels in pregnant women at their third quarter in Ethiopia, characterized as low socioeconomic condition. However, the cut-off point adopted for this assessment was twice as considered to classify the deficiency in this study $(<1,034 \mu \mathrm{g} / \mathrm{dL})$.

There are several factors that can influence the nutritional status during pregnancy and cause nutritional deficiencies. The most common are those related to socioeconomic, biological, behavioral and healthcare conditions. $21-23$ 
There are reports that the state of health of individuals who belong to the lowest social classes are less than the high social classes and is directly related to inadequate diet quality. ${ }^{21,24}$ Studies show that in low income situations there is a change in food choices, characterized by the acquisition of cheaper items and with high energy density. $7,22,23$ The first items that are out of the diet are usually the healthier food, which the population cannot reach the recommended quantities, such as grains of high quality protein, vegetables and greenery, extra virgin olive oil and fresh fruit, $6,22,25$ some important sources of vitamin $\mathrm{E}$.

Even knowing that the adequacy of dietary intake of vitamin $\mathrm{E}$ is below the recommended for the population, it is rare in the medical literature that assess the deficiency of vitamin $\mathrm{E}$ in pregnant women and its determinant factors. $24,26,27$ In this study influence of socioeconomic characteristics with alpha-tocopherol serum levels and maternal vitamin E deficiency were not found (Table 2), a result similar to a cohort on pregnant women in the Peru. ${ }^{3}$

Gurgel et al.,8 observed that women who were attended for childbirth in the private health network were more likely to have satisfactory vitamin concentrations $(\mathrm{OR}=0.3$; CI95\%: 0.1-0.8). The authors suggest that this result may have been due to the everyday intake of dietary supplements with alpha-tocopherol during the gestation, since it is known that the use of food combinations to supple- ments have a protective effect against vitamin deficiency. 28

Future investigations are necessary in order to assess whether the absence of the association of the variables with the vitamin remains during the lactation period, since a small number of cases below 517 $\mu \mathrm{g} / \mathrm{dL}$ may have influenced the analysis in this study. The apparent adequacy of alpha-tocopherol serum levels in the late pregnancy may result a physiological increase of vitamin $E$ concentration during the pregnancy, what may disguise possible cases of deficiency. This event can occur by the virtue of hyperlipidemic state associated to pregnancy, ${ }^{3}$ since the circulating lipoproteins are the means of alpha-tocopherol transport in the plasma and the concentration of alpha-tocopherol serum levels is directly associated to the total lipids levels. 26

The results of this study demonstrate that there is no association between socioeconomic variables and nutritional status of vitamin $\mathrm{E}$ in the late pregnancy. It is worth emphasizing that further investigations should be carried out to verify whether this finding remains during lactation, since it is a period of intense mobilization of vitamin $\mathrm{E}$ reserves for the production of breast milk. Thus, it is important to continue monitoring the nutritional status of pregnant women and breastfeeding women in social vulnerability situation, as an adequate maternal nutritional status reflects, mainly, in the appropriate transference of the vitamin to the fetus and subsequently via breast milk to the infant.

\section{References}

1. Wondmikun Y. Lipid-soluble antioxidants status and some of its socio-economic determinants among pregnant Ethiopians at the third trimester. Public Health Nutr. 2005; 8 (6): 582-7.

2. Medeiros JFP, Rodrigues KD da SR, Lima MSR, Silva ALC, Queiroz JLC, Dimenstein R. Alpha-tocopherol concentration in colostrum and serum of women with premature labor. J Pediatr Gastroenterol Nutr. 2016; 62 (2): 348-52.

3. Horton DK, Adetona O, Aguilar-Villalobos M, Cassidy BE, Pfeiffer CM, Schleicher RL, Caldwell KL, Needham LL, Rathbun SL, Vena JE, Naeher LP. Changes in the concentrations of biochemical indicators of diet and nutritional status of pregnant women across pregnancy trimesters in Trujillo, Peru, 2004-2005. Nutr J. 2013; 12 (1): 80.

4. Niki E, Traber MG. A history of vitamin E. Ann Nutr Metab. 2012; 61 (3): 207-12.

5. Scholl TO, Chen XH, Sims M, Stein TP. Vitamin E: increased maternal concentrations are associated with

increased fetal growth. Faseb J. 2006; 20 (4): A622.

6. Bell EF, Hansen NI, Brion LP, Ehrenkranz RA, Kennedy $\mathrm{KA}$, Walsh MC, et al. Serum tocopherol levels in very preterm infants after a single dose of vitamin $\mathrm{E}$ at birth. Pediatrics. 2013; 132 (6): e1626-33.

7. Brion LP, Bell EF, Raghuveer TS. Vitamin E supplementation for prevention of morbidity and mortality in preterm infants. Cochrane Database Syst Rev. 2003; (4): CD003665.

8. Gurgel CSS, Lira LQ De, Azevedo GM, Costa PN, Araújo JO, Dimenstein R. Comparação entre a concentração sérica de alfa-tocoferol de puérperas assistidas em maternidades públicas e privadas no Nordeste do Brasil. Rev Bras Ginecol Obs. 2014; 36 (8): 372-6.

9. Dimenstein R, Pires JF, Garcia LRS, Lira LQ De. Concentração de alfa-tocoferol no soro e colostro materno de adolescentes e adultas. Rev Bras Ginecol Obs. 2010; 32 (6): 267-72. 
10. Lira LQ De, Ribeiro PPC, Grilo EC, Lima MSR, Dimenstein R. Níveis de alfa-tocoferol no soro e colostro de lactantes e associação com variáveis maternas. Rev Bras Ginecol Obs. 2012; 34 (8): 362-8

11. Paiva-Bandeira GT, Rios-Asciutti LS, Rivera AA Rodrigues-Gonçalves MC, Pordeus-de-Lima RC, MarinhoAlbuquerque T, Marcos-de Morais R, Toledo-Vianna RP, Farias-de-Oliveira A,Teixeira-Lima R, Carvalho-Costa MJ. Relação entre renda e consumo alimentar habitual de betacaroteno, vitamina C e vitamina E de crianças. Rev Saúde Pública. 2011;13 (3): 386-97.

12. Ortega RM, López-Sobaler a M, Quintas ME, Martínez RM, Andrés P. The influence of smoking on vitamin $\mathrm{C}$ status during the third trimester of pregnancy and on vitamin C levels in maternal milk. J Am Coll Nutr. 1998; 17 (4): $379-84$.

13. Nierenberg DW, Nann SL. A method for determining concentrations of retinol, tocopherol, and five carotenoids in human plasma and tissue samples. Am J Clin Nutr. 1992; 56: 417-26.

14. Institute of Medicine. Dietary reference intakes for vitamin C, vitamin E, selenium, and carotenoids. Washington, D.C.: National Academies Press; 2000.

15. Scholl TO ST. Oxidant damage to DNA and pregnancy outcome. J Matern Fetal Med. 2001; 10 (3):182-5.

16. Scholl TO, Leskiw M, Chen X, Sims MST. Oxidative stress, diet and the etiology of preeclampsia. Am J Clin Nutr. 2005; 81 (6): 1390-6.

17. Dimenstein R, Lira L, Medeiros ACP, Cunha LRF ST. Efeito da suplementação com vitamina E sobre a concentração de alfa-tocoferol no colostro human. Rev Panam Saude Publica. 2011; 29 (6): 399-403.

18. Pressman EK, Cavanaugh JL, Mingione M, Norkus EP, Woods JR. Effects of maternal antioxidant supplementation on maternal and fetal antioxidant levels: a randomized, double-blind study. Am J Obstet Gynecol. 2003; 189 (6): 1720-5.

19. Baydas G, Karatas F, Gursu MF, Bozkurt HA, Ilhan N, Yasar A, Canatan H. Antioxidant vitamin levels in term and preterm infants and their relation to maternal vitamin status. Arch Med Res. 2002; 33 (3): 276-80

20. Weber D, Stuetz W, Bernhard W, Franz a, Raith M, Grune $\mathrm{T}$, Breusing N. Oxidative stress markers and micronutrients in maternal and cord blood in relation to neonatal outcome. Eur J Clin Nutr. 2014; 68 (2): 215-22.

21. Darmon AN. Does social class predict diet quality? Am J Clin Nutr. 2008; 87 (5): 1107-17.

22. Darmon N, Briend A, Drewnowski A. Energy-dense diets are associated with lower diet costs: a community study of French adults. Public Health Nutr. 2004; 7 (1): 21-7.

23. Andrieu E, Darmon N, Drewnowski a. Low-cost diets: more energy, fewer nutrients. Eur J Clin Nutr. 2006; 60 (3): 434-6.

24. Traber MG. Vitamin E inadequacy in humans: causes and consequences. Adv Nutr An Int Rev J. 2014; 5: 503-14.

25. Drewnowski A, Darmon N. The economics of obesity: dietary energy density and energy cost. Am J Clin Nutr. 2005; 82 (Suppl. 1): 265-73.

26. Traber MG. Vitamin E. In: Erdman Jr JW, Macdonald IA ZS, editor. Present Knowledge in Nutrition. 10th ed. Washington: ILSI PRESS; 2012. p. 214-29.

27. Dror D, Allen L. Vitamin E deficiency in developing countries. Food Nutr Bull. 2011; 32 (2): 124-43.

28. McBurney MI, Yu EA, Ciappio ED, Bird JK, Eggersdorfer M, Mehta S. Suboptimal serum $\alpha$-tocopherol concentrations observed among younger adults and those depending exclusively upon food sources, NHANES 2003-20061-3. PLoS One. 2015 ; 10 (8): e0135510.

Received on June 9, 2016

Final version presented on January 23, 2017

Approved on January 26, 2017 